\title{
The Architect as Producer: Hannes Meyer and the Proletarianisation of the Western Architect
}

\author{
Amir Djalali
}

'The revolutionary intellectual appears, first and foremost, as a traitor to his class of origin.' This betrayal consists, in the case of the writer, in behaviour which changes him from a reproducer of the apparatus of production into an engineer who sees his task as the effort of adapting that apparatus to the aims of the proletarian revolution.

Walter Benjamin, 'The Author as Producer' (1934)

The architects of the modern movement advocated the advent of mechanisation and standardisation in architecture and its design procedures. Rejecting the position of the architect as a talented individual infused with artistic genius, they promoted an architecture based on repetition and typisation, in which collective needs are placed before the individual's inspiration. Nonetheless, most of the time this emphasis has remained on an ideal level. In the work of the European masters, ideas of standardisation and the assimilation of architecture with industry continued on a rather superficial level, producing at best a new image or a new style for architecture. The ways in which architecture was produced remained quite traditional: except for some experimental schemes, the new architecture was still built relying on pre-industrial craftsmanship. Similarly, the organisation of the architectural offices of the modern movement masters remained those of the traditional artist's workshop. Architectural education, even in its most advanced experiments, was still based on this tradition. Despite Gropius's pleas for the unity of art and technique, the teaching at the Bauhaus was still based on a romantic ideal of formal and artistic autonomy. Industry and the modern world remained somehow an ideal reference; the intellectual separation of the architect from the realm of the labour market and its laws was cherished as a guarantee of artistic freedom.

One exception to this approach is constituted by the work of Swiss architect Hannes Meyer. [fig. 1] Unlike his more famous contemporaries, Hannes Meyer's effort was not concentrated on the construction of new forms of aesthetics and space, but rather on the transformation of the procedures and means through which architecture and the city were produced. For Meyer, this meant radically rethinking not only the means by which architecture was built. Reconstructing architecture also implied understanding the role of architects in the building process, their languages and means of production, and the ways in which they collaborate with each other and with the builders. Ultimately for Meyer, modern architecture did not mean constructing a new image for the city, but rather questioning the very basis on which architecture had been considered since its 'invention' during the Renaissance; namely, by undermining the tendency to see the architect as the only author and deus ex machina of architecture. In other words, Meyer's practice was based on a critique of the role of intellectual labour vis-à-vis the pervasiveness of industry in the contemporary world. The scandalous outcome of such a critique would not only be the destruction of architecture as an autonomous discipline and its assimilation in the practice of building. Meyer also 
saw the necessity to destroy architects as intellectuals and assimilate their labour to that of salaried workers in a conscious process of proletarianisation.

This article explores a series of concepts developed by Hannes Meyer between 1927 and 1932, during his time as director of the Bauhaus in Dessau (1928-30) and during the first years of his Soviet experience. In these years, Meyer had the opportunity to develop and test new forms of organisation for the production of architecture in his everyday practice as an architect, teacher and school director. His project was destined to fail. Meyer was forced to flee and live in exile many times during his life. Despite the good financial performance of the Bauhaus under his direction, he was expelled from the school because of his ill-concealed leftist sympathies. Free to express his Marxist positions, in the Soviet Union he became an ardent Stalinist. Even so, his loyalty to the dominant doctrine still did not prevent him from being blacklisted as a petty bourgeois advocate of modernist aesthetics. In Mexico, his fame as a Stalinist prevented him from receiving commissions after Trotsky's assassination. In his last years, Meyer lived isolated from the rest of the design world: his Bauhaus experience was erased from the construction of the Bauhaus myth during the post-war period. At the same time, DDR authorities did not like his prewar avant-garde allegiance - in particular his experience as editor of $\mathrm{ABC}$ - and saw him as a bourgeois formalist. ${ }^{1}$

Nevertheless, Meyer's liminal position, which blurred the distinction between avant-garde and everyday practices, revolutionary agitation and technical work, is particularly instructive in investigating the genealogy of the contemporary organisation of architectural production. In his archaeology of the architectural profession, Andrew Saint has defined the case of Meyer and his exiled fellow comrades as a continuing challenge to the ideology and the orthodox representation of the Western architect. ${ }^{2}$ Although when Saint was writing in 1983 it was still possible to claim the existence of such an orthodoxy, today we are left with professional figures deprived of their previous certainties and defined role in society. Some of Meyer's most visionary prophecies on the nature of architectural labour seem fully realised today, well beyond his own original intentions. 'Diffused intelligence', multidisciplinarity, participation and 'networked practices', far from being revolutionary concepts, are at the core of architectural production today, and the proletarianisation of architectural labour is not emerging as the outcome of a revolutionary process.

Meyer's work as agitator, organiser and school director provides the opportunity to develop a theory of intellectual labour and knowledge production in architecture. This means investigating not only the techniques, languages, institutions and forms of organisation through which architectural knowledge is produced, but also sketching the affective and subjective portrait of architects in a moment in which their traditional role is deeply questioned.

\section{The radicalisation of the Bauhaus curriculum}

Meyer was appointed as a director of the Bauhaus in 1928, after Gropius's resignation. Gropius himself suggested Meyer as his successor, since, as he personally declared, he did not suspect his political leanings. On the contrary, he appreciated Meyer's designs for the Petersschule in Basel and his entry for the Society of Nations competition, and he greatly valued Meyer's polemic attitude and social involvement as key elements for reconstructing the Bauhaus' unstable situation both within and outside the school. ${ }^{3}$

Despite the general prestige that the Bauhaus school had among designers and prospective students, it had to face the political suspicion of the reactionary political forces that were growing in the province of Anhalt, and in particular in the city of Dessau. Gropius's idea to move the school to the liberal-democratic Dessau instead of to the more 


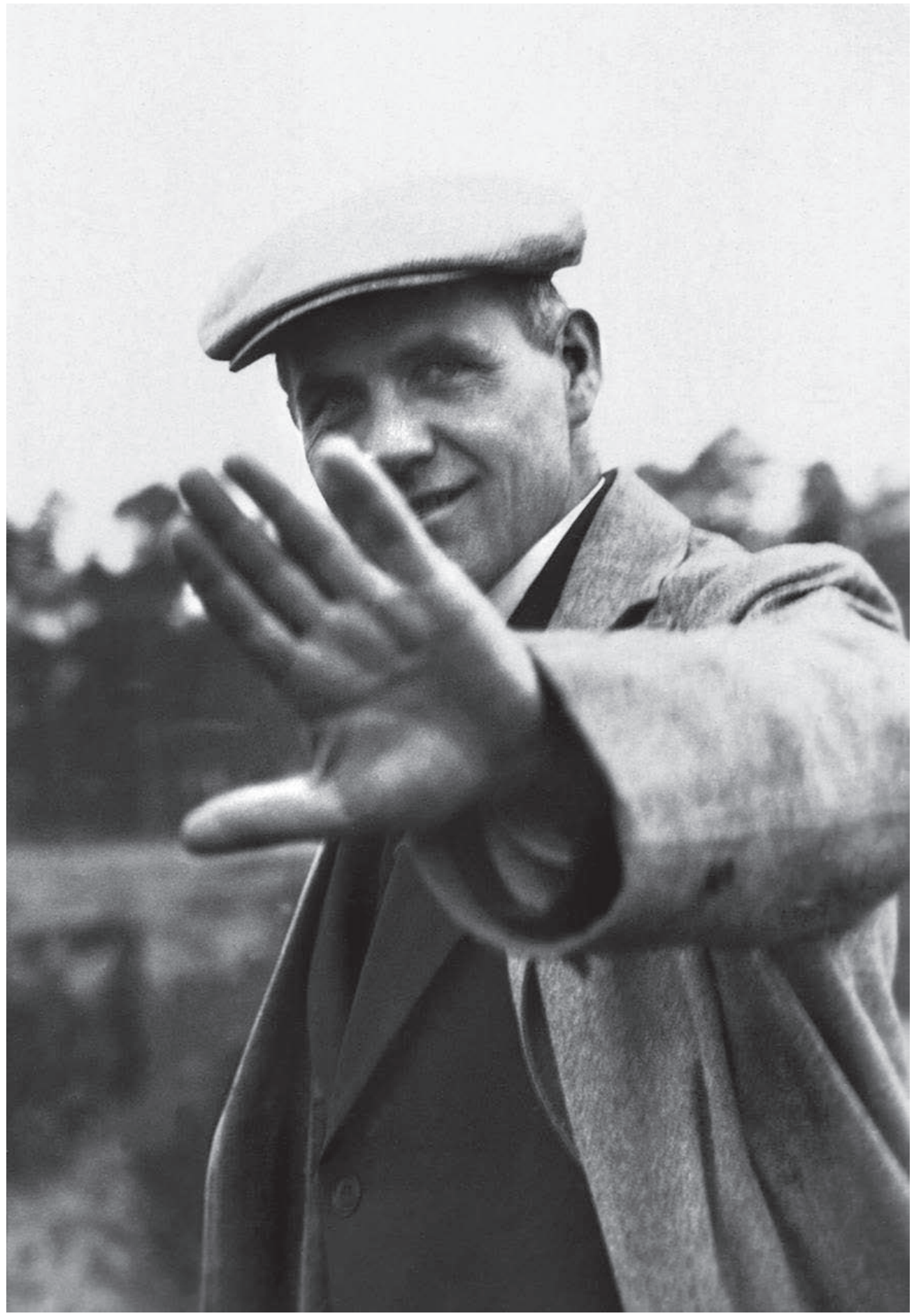

Fig. 1: Hannes Meyer at the site of the Federal School of the General Trade Unions (ADGB) in Bernau near Berlin (1928). Photo: Erich Consemüller(?), Stephan Consemüller, Stiftung Bauhaus Dessau. 
progressive social-democratic city of Frankfurt, was meant to grant a larger degree of didactic autonomy to the school, thus avoiding the capillary control of the Frankfurt authorities over the architecture of the city and its planning matters. ${ }^{4}$ But the same political forces in which Gropius trusted would be those that forced Meyer to resign.

On the internal front, the school was divided between the painter's attitude, epitomised by Klee and Kandinsky, who privileged a didactic approach based on the teaching of form and composition, considered autonomous entities with their own specific laws; and Gropius's option for a socially oriented workshop practice capable of training a new kind of professional figure for the rising industrial and machine age. This new practitioner would have to be able to cope with the needs of standardisation and mass production imposed by new emerging lifestyles. ${ }^{5}$ But while in 1919 this programme was revolutionary and accompanied by a great wave of enthusiasm, by 1926 it sounded like an empty academic exercise.

By that time, standardisation, mass production and mechanisation were already much more developed than avant-garde artists could have ever imagined, and they entered the everyday life of the masses without the help of the reformist programmes of the Bauhaus. ${ }^{6}$ On the contrary, the Bauhaus proved unable to cope with these social transformations, limiting itself to the promotion of a new aesthetic: a Bauhaus style. Despite its programmatic intentions, the Bauhaus ended up isolating itself more and more from society. At best, the masters employed the teaching at the Bauhaus as a tool to procure personal commissions, as in the case of the buildings by Gropius in Dessau, or the production of Marcel Breuer's steel tube chairs. ${ }^{7}$

The social reality of the time seemed much more advanced than any programmatic manifesto. This atmosphere is captured in a text that Hannes Meyer wrote in 1926 titled 'Die neue Welt' (The New World). ${ }^{8}$ In this peculiar text, Meyer starts enumerating, in an apparently random order, a series of technical achievements of the machine age and the benefits they had brought to the lives of the masses. In the form of a cinematic montage or of a Dada collage, Meyer juxtaposes the names of brands, patents, sportsmen and actors as the epic characters in the construction of a collective mythology of the present. No distinction is posed between high and low forms of culture. The roles of Sigmund Freud, Anatole France and Albert Einstein in shaping the new world are no less than those of Douglas Fairbanks, Suzanne Langlan and Paavo Nurmi. The development of radio, DIN standardisation norms and the League of Nations are presented on the same level as bobbed haircuts, advertising and the tango. In his rhythmic, obsessive juxtaposition of high and low registers, spiritual and technical language, literary and popular idioms, Meyer is able to sketch the emergence of new forms of metropolitan life. In this process, Meyer finds the elements for the liberation of mankind from the bonds of localism, tradition, patriarchy, individualism, and, ultimately, from the bonds of human nature itself. Constructivism for Meyer means the possibility of actively organising collective forms of perception and coexistence. Through its new means of constructive expression, architecture would be nothing other than the possibility of directly achieving this constructive ethos. In this sense, function supplants composition. Composition is the process of form making based on alleged internal aesthetic properties. Conversely, function is form making based on the capacity to shape life. ${ }^{9}$

Meyer's account of art in 'Die neue Welt' tells of the situation in which he found the Bauhaus when he arrived in 1926. Meyer rejects altogether the possibility of the autonomy of art and the artist. For Meyer, art has the capacity to anticipate what has not yet become possible. In the words of Piet Mondrian: 'What has been achieved so far' is 'a 
substitute for the better achievement that still has to be achieved. ${ }^{10}$ Meyer was probably sensing that the role of art had already been superseded by life itself, and that it was time to downscale its role in the Bauhaus curriculum.

The style and content of 'Die neue Welt' were not scandalous at the time, and Gropius was able to find concepts that were very close to those contained in his early writings. ${ }^{11}$ Despite its assertive tone, the article can still be read as an idealistic declaration of faith in a harmonious and progressive direction of history, in which capitalistic industry actively paves the way for human liberation. In his attempt to direct the Bauhaus curriculum towards more constructive and social topics, Gropius first invited Meyer to chair the new building department at the Bauhaus, and then, forced to resign as its director, appointed him his successor. ${ }^{12}$

Yet the way in which Meyer structured his directorship was far from a reassuring separation between intent and practice. On the contrary, Meyer actually put into practice what Gropius had theorised in the preceding years. Despite the subsequent polemics between the two, and historians' narratives that distinguish 'two' Bauhaus, one can find a singular continuity between the periods in which Gropius and Meyer were directors. Despite Meyer's attempt to take all the credit for the miraculous financial performance of the Bauhaus in the years 1928-30, the seeds of this success were sown by Gropius in his last years as director. Meyer's genius was to accelerate the process that Gropius had already set in motion and to dramatically unveil its internal contradictions. ${ }^{13}$

When Gropius moved the school to Dessau, he sought to find links with local industries and founded a commercial company called 'Bauhaus G.m.b.H.'. In 1926, Joseph Albers was appointed as the preliminary Bauhaus course master. His approach differed from his predecessors; it abandoned their spiritualistic and perception-based approach to form, colour and materials. Instead, Albers focused on constructive principles, economy and efficiency, privileging an inventor rather than a creator approach. The appointment of Bauhaus alumni as workshop masters allowed them to take advantage of the skills of new professional figures who were able to combine a theoretical and a practical approach to subject matter. ${ }^{14}$

In 1928, Meyer reorganised the Bauhaus course structure. [fig. 2] His programme sought to put the school in the service of the collective needs of the New World: 'Do we want to be in tune with the necessities of the world out there and collaborate with the formation of new forms of life, or do we want to remain an island in which personal values are cultivated?'15 Meyer organised the school's programme into four curricula: weaving, advertising, interior design and building. The first term was a common preliminary course led by Joseph Albers, meant to wean the student 'away from tradition as much as possible, and to awaken in him the forces dormant in everyone'. ${ }^{16}$ For the building curriculum, Meyer envisioned the first two general terms of a building workshop, in which the manual skills and craftsmanship of the students were trained. The fourth, fifth and sixth terms were dedicated to 'building theory', which introduced science and social theory in order for the student to 'fit his activities into modern society', and to achieve a scientific definition of building as 'the organisation of all life's processes'. ${ }^{17}$ The final seventh, eighth and ninth terms were dedicated to the building studio, which entailed working on commissions for external partners, thus dealing with real-life building problems. The commissions included the realisation of ninety working-class dwellings in Dessau-Törten, which had been already initiated by Gropius, and the design for the worker's union school in Bernau. [fig. 3] The sixty rooms of the school were furnished with Bauhaus furniture. The weaving workshops produced prototypes for the neighbouring industries, including new 


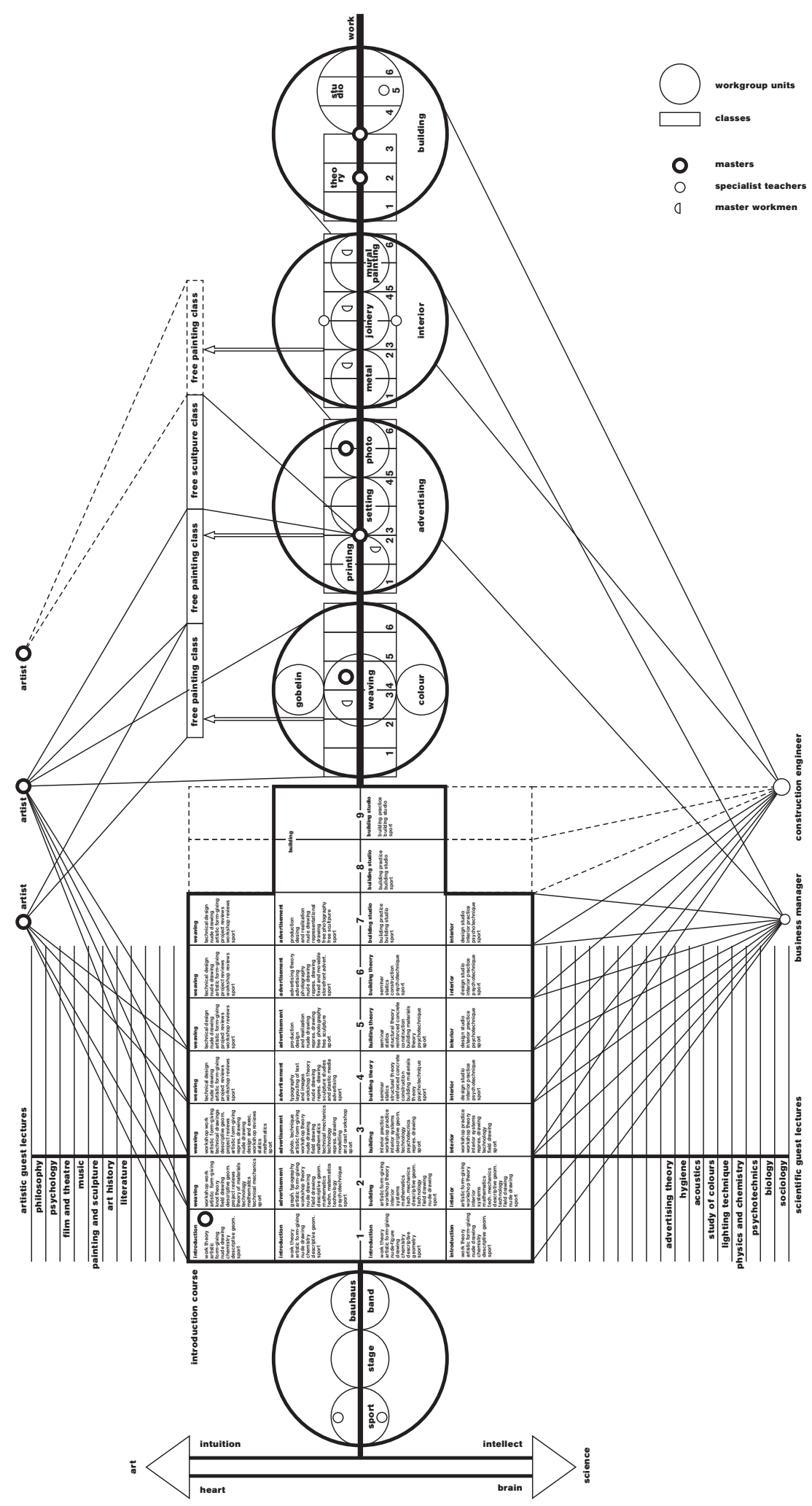

Fig. 2: The curriculum structure of the Bauhaus, 1928. Source: HAB Dessau, redrawn by the author. 


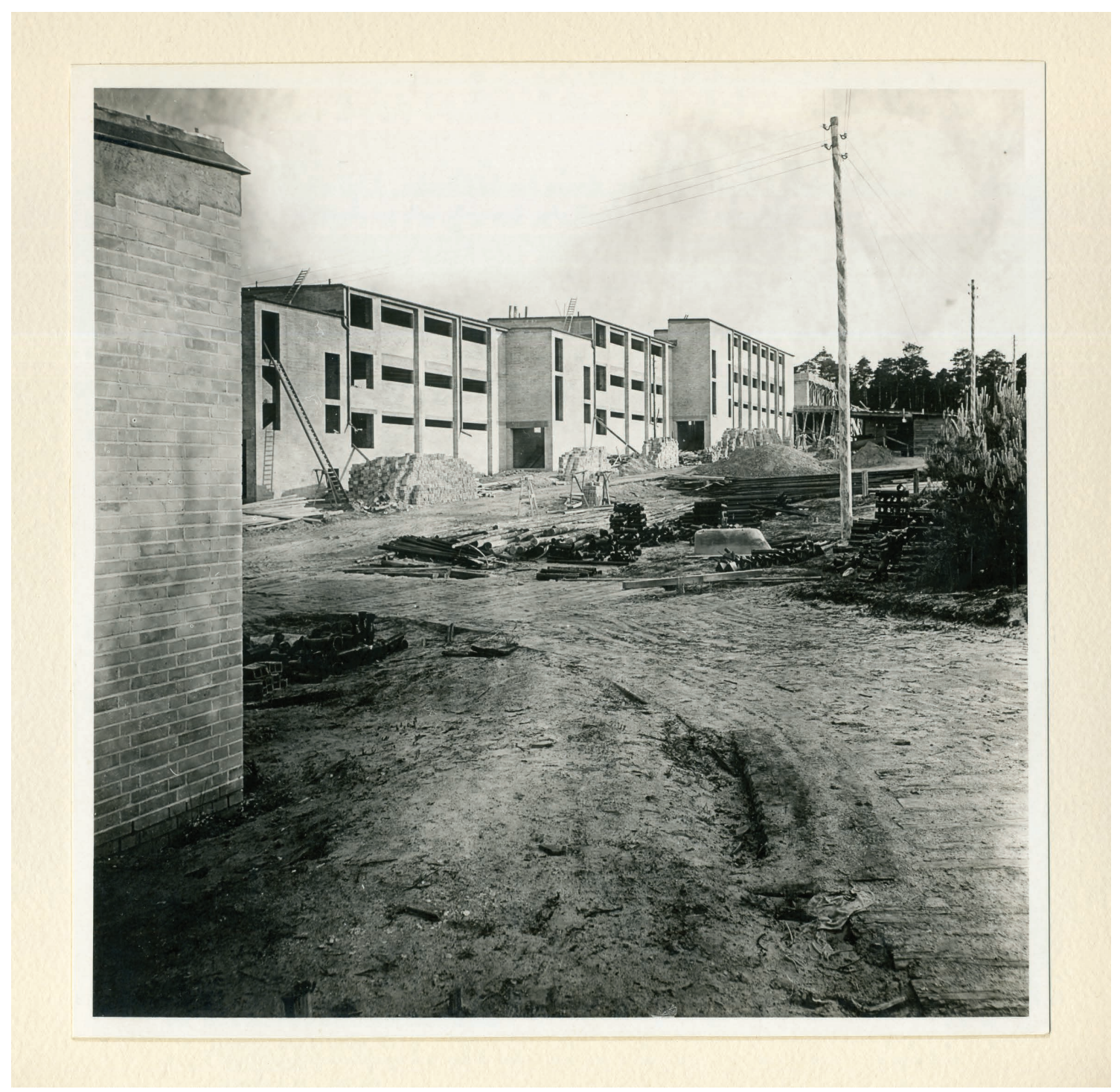

Fig. 3: Hannes Meyer, Hans Wittwer and building workshop Bauhaus Dessau (design). Trade Union School of ADGB (Allgemeiner Deutscher Gewerkschaftsbund) Bernau near Berlin, 1930. Source: Bauhaus Dessau Stiftung. 
experimental materials. The Bauhaus wallpaper clad 'more than 20,000 rooms in Germany and neighbouring countries', and Bauhaus advertisement posters and catalogues were printed for various firms and public authorities. The new photographic workshop was employed to document construction sites and to work in conjunction with the advertisement workshop, while the metal workshop received commissions from various lamp manufacturers. Even the theatre workshop began to function as an autonomous company, touring both in and outside Germany and exposing its social critique plays to a wider public. $^{18}$

New teachers were appointed for the architecture department, such as Ludwig Hilberseimer, Mart Stam, Anton Brenner, and Hans Wittwer, who was also Meyer's collaborator for the designs of the Petersschule and the League of Nations building.

In this context, the painting classes led by Kandinsky and Klee were removed from the official curriculum and relegated to the role of elective classes. Much emphasis has been placed on showing the reductionist approach to architecture that Hannes Meyer introduced into Bauhaus courses, which was summarised in two articles/ manifestos published in the school's magazine. ${ }^{19}$ In these fast-paced texts, written with no capital letters and with a sparing use of punctuation, Meyer builds upon the themes of 'Die neue Welt' while pushing the negation of artistic composition to an extreme level and in open opposition to the Bauhaus master painters. ${ }^{20} \mathrm{He}$ proposes overcoming an individual and emotive artistic discipline through the practice of 'pure construction', seen as a biological function of a collective social body governed by impersonal and objective parameters. Yet is it clear that for Meyer these parameters are not already given, they have also to be constructed. In fact, the selection and the order of the requirements that Meyer prescribes for building a house are the outcome of a specific choice that might have puzzled more traditional functionalists. ${ }^{21}$ The artist thus becomes an organiser of collective life beyond the constraints of tradition and the nation state. The sheer reductionism of Meyer's 'building' has the precise scope of liberating the intrinsic richness of life in all its forms: 'Because this doctrine of building is close to life's realities, its theses are constantly changing: because it finds concrete existence in life, its forms are as rich in content as life itself. "Richness is all".'22

This organisational effort was shown not only in external commissions but also and especially within the life of the school and in the cooperative organisation of the workshops. No student worked alone. In dealing with commissions, students and masters were organised around multidisciplinary 'vertical brigades', comprising students from various years and various backgrounds. In this way younger students were helped by older ones under the supervision of a master. Meyer sought to ban individual protagonism from the school, both in the masters and in the students:

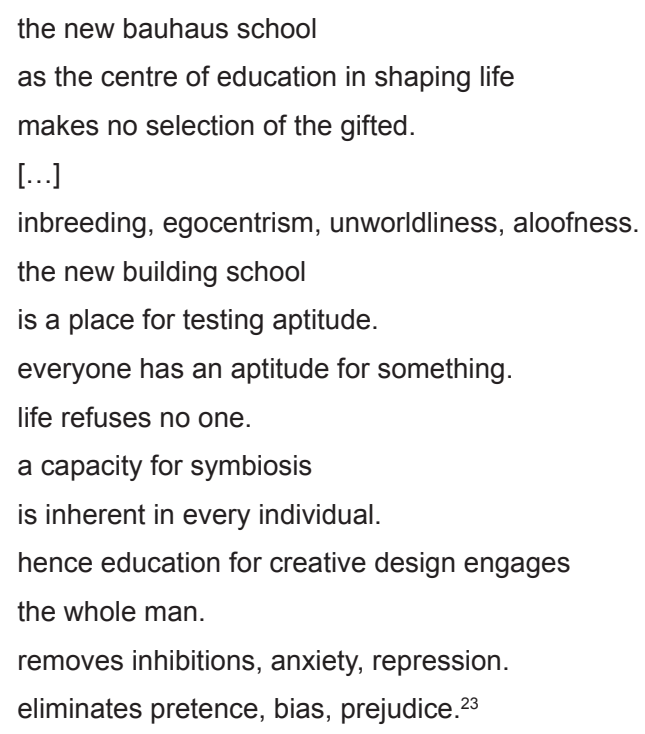

Besides the director's bombastic declarations, the school actually experienced an unprecedented period of financial prosperity. The revenues doubled between 1928 and 1929, and the number of 
students rose from 160 to 197. During the academic year 1929-30, the administration was even able to grant a salary to the students and to redistribute royalties among the workshops. ${ }^{24}$

The reasons for Meyer's dismissal from the Bauhaus are well known. He was accused of allowing politics to enter the school and of tolerating the emergence of an anti-Nazi Marxist student organisation in a school that, according to the idea of its founder, should be kept apolitical. With the accusation of being involved in a solidarity fundraising to help the striking miners in Mansfeld, Meyer was removed from his office in 1930 by a decision of the Dessau Mayor Fritz Hesse. ${ }^{25}$ In actuality, the reactionary authorities of Dessau were unable to tolerate a financially and politically autonomous Bauhaus. The school that should have been kept 'apolitical' became a propaganda instrument for the official politics of the municipality. Following Gropius's advice, Mies van der Rohe was appointed as the new director. He had to enforce the original, apolitical discipline of the school with the help of the police. $^{26}$

\section{The architect in class struggle}

Freed from the cautions that his office duties imposed on him, Meyer retroactively espoused his opponents' accusation of Marxism, even going so far as to relabel his experience at the Bauhaus as the 'Krasnyi Bauhaus', or the 'Advanced Institute for Marxist Architecture'. ${ }^{27}$ Nevertheless, Meyer never became part of any Communist party, and his Marxism was highly idiosyncratic and cannot be ascribed to any official doctrine. Somewhat naively, Meyer moved to the Soviet Union, where he expected to find socialism actually realised. ${ }^{28}$ [fig. 4] But in his writings from the years 1930-32 one can also read a disenchanted, lucid view of his experience at the Bauhaus and the ongoing transformation of architectural practice under capitalist rule.

Meyer declares the liberation of the architect's work from the fetters of private property under a planned economy. ${ }^{29}$ Yet his Soviet production does not show the originality and power of his early work in Western Europe. On the contrary, it seems that his best production stemmed from the internal contradiction of the capitalistic economy itself. Paradoxically, it was his experience under the highly advanced capitalism of 1920s Germany that gave him the opportunity to produce the best results of his political project. Meyer was conscious of the fact that the architect is but a cog in a system of power relations, and that no Marxist or revolutionary architecture can ever exist. ${ }^{30}$ Like Le Corbusier, Meyer saw architecture as fundamentally opposed to political revolution. But while Le Corbusier advocated architecture as the last hope against political turmoil, Meyer saw revolution as a positive historical force, whose inherent rationality would make architecture redundant. It is in this sense that Meyer's interest in the history of architecture should be read. Indeed, he attempted to bring history back into his teaching activity after Gropius had eliminated it from the Bauhaus curriculum. 'At the Bauhaus in Dessau,' Meyer declared, 'I constantly annoyed students with the analysis of architectonic orders of various epochs, with the analyses of the plans of Paris, Ghent, Basel, and their relation with the dominant social systems in which they arose. ${ }^{31}$ History was no longer seen as a repository of models to be imitated, but as a testing ground for the role of the architect within the power relations that characterise every epoch.

Through his historical analysis, Meyer sensed an ongoing trend of the 'technical collectivisation of bourgeois life', which was manifested first in luxury hotels and resorts, then spread with the Western architect's proposal for bourgeois collective houses. 'In the dying bourgeois building industry,' he declared, 'the germs of the new proletarian building industry are spreading. ${ }^{32}$ Yet the bourgeoisie would not be able to free itself. A political intervention was necessary to turn the crisis into a project of liberation, 
freeing science, art and technology to achieve their full potential of emancipation. In this way, one can give new meaning to Meyer's early texts. 'Die neue Welt' in this context appears less a reductionist sociological analysis and more a retroactive manifesto for modernity: Meyer does not describe the reality of the present but isolates a tendency within it with the scope of actively changing it. Our life is not standardised, mechanised and internationalised enough: capital impedes rather than promotes the rational potential that is immanent in the development of our society.

Within this tendency internal to capitalist development, Meyer saw architecture becoming science and the end of the division between architecture and building. In other words, Meyer saw the end of the division between the intellectual labour of the architect and the manual labour of the builder. 'The increasing exacerbation of the crisis will suffocate the class-conscious architect, but from a political point of view, he will become more and more emancipated from his waiting state. He knows that, as an intellectual worker at the drafting table, he is a slave like his comrade - the construction worker. ${ }^{33}$ But in the view of militant architects, this is a welcome development that contributes to their liberation and final assimilation into the proletarian communal form of life.

It is for this reason that Meyer transformed the Bauhaus into a factory and its workshops into research and development departments for the most advanced industries of the day; it was his attempt to accelerate the historical tendency and unleash its unsettling potential. The salary paid to the students was a central part of this strategy. By transforming students into workers, Meyer achieved a twofold result. On the one hand, he allowed students from proletarian backgrounds to access the school, prefiguring a higher education for the masses; and on the other hand, Meyer proletarised the students coming from bourgeois families, introducing them to salaried work, levelling the class differences within the workshops and promoting cooperation between students. ${ }^{34}$ The becoming-proletarian of the Western architect is a joyful process when it is organised and well funded.

\section{The underground legacy}

Meyer's directorship was eradicated from the official historical chronicles of the Bauhaus and dismissed as a negligible incident. ${ }^{35}$ Ten years after his death, controversies surrounded the publication of the first monograph in his honour, edited by Ulm Hochschule für Gestaltung professor Claude Schnaidt. Its publisher Arthur Niggli felt the necessity to write an afterword to distance himself from the positive account that the book gave of Meyer. The epilogue contains a letter that Gropius had sent to Tomas Maldonado some years before, in which the German master discredits the personality and work of Meyer as a Bauhaus director. ${ }^{36}$ Despite the positive re-evaluation of the work of Hannes Meyer in Italy in Manfredo Tafuri's Venice circle (due to Francesco Dal Co's 1969 anthology of Meyer's texts for the publisher Marsilio), ${ }^{37}$ and Aldo Rossi's inclusion of Meyer's Petersschule in Basel among his selection of canonical 'rational architecture' for the 1973 Milan Triennale, ${ }^{38}$ an unprejudiced rediscovery of Meyer's work only appeared during the celebration of Meyer's centenary in 1989, which also corresponded with the reunification of Germany and the end of the cold war. ${ }^{39}$

For Schnaidt and Maldonado, recuperating the last Dessau years of the Bauhaus was part of an attempt to set their work at the Hochschule für Gestaltung in continuity with that experience, and, in particular, with the attempt to merge the activity of the school with the needs of society and industry. ${ }^{40}$ For an almost opposing reason, Dal Co and Tafuri saw Meyer's trajectory as part of their polemic against the progressive culture that had dominated Italian design culture since the sixties. Meyer's opposition to Gropius and the design ideology of the 


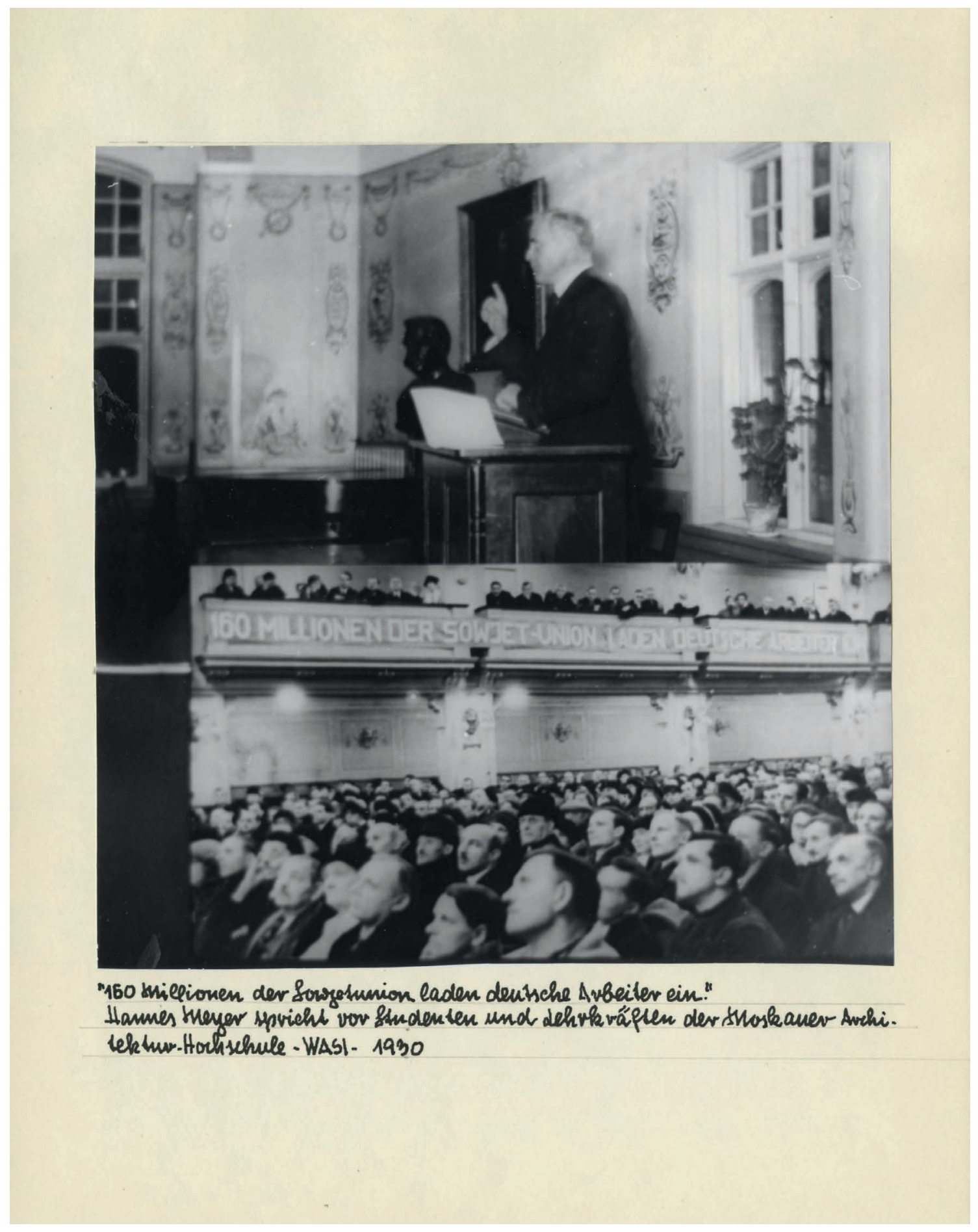

Fig. 4: Hannes Meyer lecturing at the School of Architecture in Moscow (WASI), end of 1930. Documentation of the former Bauhaus Student Konrad Püschel, Stiftung Bauhaus Dessau. 
Bauhaus, as well as his capacity to give a political answer to the impasse of the school, was seen as an important precedent for the Italian debate over the role of intellectuals in capitalism's new developments. In this context, Meyer was associated with the German tradition of 'negative thought', which, according to the Venice intellectuals, constituted the most advanced experience of bourgeois ideology in its capacity to accept the irreconcilable contradictions contained in reality and turn them into positive instruments for development. ${ }^{41}$

For Rossi and his collaborators, Meyer was an 'exalted rationalist', for whom the compulsive adherence to a rational, scientific and normative system led to unprecedentedly poetic results, encouraging the proliferation of architectural form instead of repressing it. ${ }^{42}$ [fig. 5] On the contrary, the work of the Swiss master inspired the anti-formalist, sociologically oriented analyses of the construction industry which Jörn Janssen led, first at the ETH (occupying the same chair that was later held by Rossi) ${ }^{43}$ then later, together with Linda Clarke, at the series of Bartlett International Summer Schools until $1995 .{ }^{44}$

In the 1990s, the work of Meyer was once again recuperated in the debate over the autonomy and criticality of architecture. For Hilde Heynen, Meyer's Petersschule, by imposing its architecture against the contextual condition of the site, and by its humorous use of sunlight calculations, is an example of the militant negativity of architecture in resisting given social constraints and constructing autonomous domains of resistance. ${ }^{45}$

Instead of dealing with the autonomy of the object, K. Michael Hays approached the architecture of Hannes Meyer and his fellow Bauhaus teacher Ludwig Hilberseimer from the point of view of the modern subject. According to Hays, the architecture of the two masters, often considered a minor expression of modern architecture, shows the most original aspect of modernism: the dissolution of the alleged universality of the bourgeois subject and the construction of subjectivity as an open field of experimentation. ${ }^{46}$

Today we are probably facing a new wave of rediscovery regarding Hannes Meyer's work. ${ }^{47}$ Such an interest can be seen as part of the current boom of theoretical production in architecture, and it is possibly connected to the present economic crisis. ${ }^{48}$ If in the 1990s the interpretation of Meyer's architecture stemmed from reading French poststructuralist theory, it seems that our allegiance with Meyer today is mediated by Italian political thought; in particular, the various analyses of the centrality of cognitive work in the post-Fordist economy. ${ }^{49}$ In this context, Meyer's emphasis on cooperation and his idea of architecture as a collective production is read through the analyses of cognitive labour developed by Italian Autonomous Marxism. In this sense, the autonomy of architecture as a discipline is displaced in favour of the redefinition of the autonomy of the producers of architecture, through the liberation and 'self-valorisation' of the forces of social cooperation. ${ }^{50}$

At the same time, the Meyer project for a Co-op Zimmer resonates with the contemporary uprooted condition of precarious cognitive workers. The emphasis on occupation and use rather than on ownership and belonging provides a precedent for the construction of a contemporary ascetic form of life opposed to the austerity measures imposed by mortgages and debts. ${ }^{51}$

\section{Meyer and us}

It is uncanny to note how some of Meyer's prophecies, once seen as the delirium of a Stalinist zealot, have become part of our everyday practice as architects, students or educators. Ironically, this did not happen as a consequence of the end of the capitalist economy, but during its most advanced developments. 


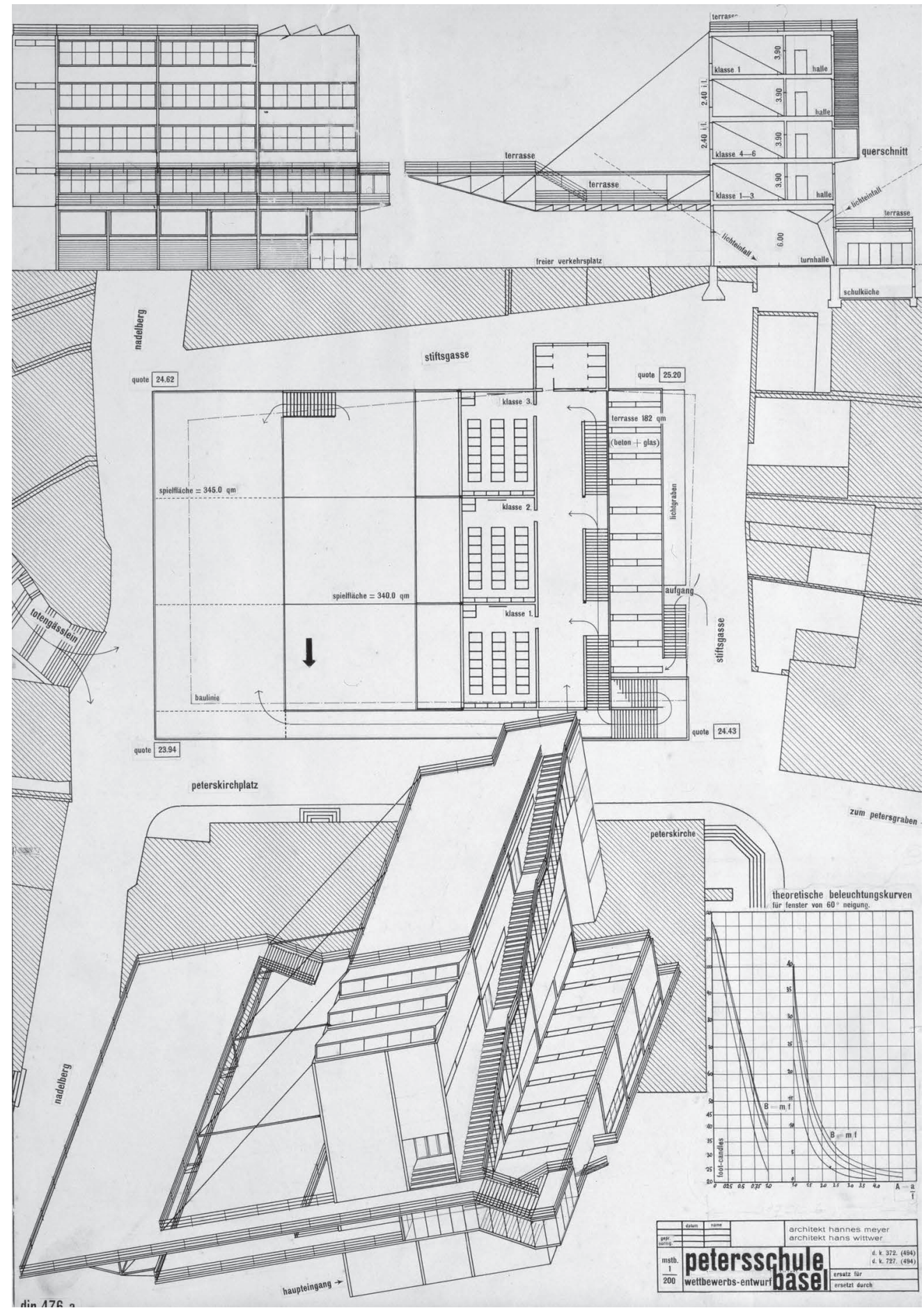

Fig. 5: Hannes Meyer, Hans Wittwer and building course Bauhaus Dessau (design). Competition design for the Petersschule, Basel, 1926. Stiftung Bauhaus Dessau. 
Beyond a merely superficial stylistic point of view, the introduction of digital technologies in design has had a threefold effect on the organisation of architectural work and radically changed the role of the architect in the design process. This has occurred to such a degree that historian Mario Carpo speaks of the end of architecture, defined by Filippo Brunelleschi and Leon Battista Alberti as an allographic, notational and authorial art. ${ }^{52}$

On the one hand, through parametric design, the final form of a building is not fully controlled by the will of the single designer. The architect is no longer in charge of intellectually conceiving a building form, instead he becomes an organiser of the diagram of a building expressed as a series of relations between environmental, economic and social parameters, and formalised as an algorithm. Through the variation of such parameters, the same code can produce many different formal outcomes, which the designer cannot predict. Meyer's antiformalism and functionalism is today completely realised to a level that Meyer himself could not foresee.

Secondly, digital prototyping and fabrication have removed the distance between the architect as an intellectual worker in charge of the creative design phase, and the builder, a mere executor of the architect's will. On the contrary, the possibility of rapidly passing from design to prototyping virtually removes the six-century-long architectural division of labour.

Thirdly, building design today is executed less and less by architects alone and is more and more conceived as a collaborative enterprise between a series of social actors and technical specialists. This is made possible by the widespread use of Building Information Modelling platforms (BIM). ${ }^{53}$ Computer Aided Design (CAD) software used by architects and engineers as a digital substitute for the drafting table did not change the traditional role of the architect as the producer of drawings - the symbolic representations of physical building elements produced in lines and hatches. Now, however, building information models manage whole series of symbolic objects that not only represent traditional building elements in terms of two-dimensional parallel projections or threedimensional models, but are also multi-dimensional representations of material characteristics of the objects to be built, while also carrying additional information, such as the climatic performance of interior environments, programmes and functions, building and operational costs, financial data, maintenance information, and so forth. In a way, building information models become a 'permanent, interactive digital doppelgänger of each object of design', allowing the control of the architectural object far beyond its physical configuration. ${ }^{54}$ The advantage of such a modelling technology is the possibility it provides for various specialists to collaborate on a variety of aspects of the same design through a standardised protocol. Interestingly, the definition of such protocols is not imposed as proprietary software by private companies but through the work of national or international standardisation committees, and several open-source BIM platforms are being developed by independent communities. ${ }^{55}$ Meyer's dream of a shared, standardised, universally valid, multidisciplinary and collective design workflow platform is a reality of today's architectural practice. In this context, the 'death of the author' is no longer the provocation of a limited number of avant-garde artists, but the working method of the world's largest design consultancy firms.

As Meyer wanted, architects have really become organisers and their work has become more and more political: not only do they act as mediators between different technicians - structural engineers, HVAC specialists, financial programmers, etc. - but also as mediators between various economic interests, as well as managers of social conflicts between land owners, inhabitants, developers and city administrations. ${ }^{56}$ 
Ironically and in addition, Meyer's project for merging education with the social productive reality outside academia is today one of the pillars of neoliberal economic doctrine and the organising principle of all higher education institutions. Faced with the shrinkage of public support, universities have turned themselves into corporations, establishing links with external private companies and turning to private funds to support their research activities. ${ }^{57}$

If universities have become factories, then students have really become workers in a seamless productive system comprising academic institutions, private corporations and individual freelance work. Yet, contrary to what Meyer achieved at the Bauhaus, students today do not receive any salary for their activities as students. On the contrary, they have to pay tuition fees that are dramatically rising every year, and many of them are forced to contract study debts with banks. Debt also limits the autonomy of new graduates, whose capacity to choose good jobs is hampered by the necessity of repaying their creditors. ${ }^{58}$ In a thriving job market this problem is less noticeable. However, as an effect of the 2008 crisis the architectural job market has shrunk significantly, along with salaries. In this context, students and graduates are often forced to perform unpaid or underpaid work in the form of internships, and to increase their workload. Architects today have fewer possibilities of finding permanent and fulfilling jobs than in the past; and, probably more than other professional group, they are faced with the prospect of a precarious lifestyle..$^{59}$

As Hannes Meyer wanted, architects today are becoming proletarians. But the destiny of the proletarisation of the architect is not affecting only the 'class-conscious architect' as a joyful existential project of liberation from bourgeois morals. On the contrary, it is affecting architects against their will, bringing about the 'sad passions' of competition, depression and cynicism. ${ }^{60}$
In the early 2000s, many analysts expressed their faith in digital technologies and the neoliberal era, declaring the end of theory, seen as a device hampering the free development of positive market forces. ${ }^{61}$ Today it is clear that the market is not autonomous and that capitalism will not die a natural death. Concepts such as 'projective' or 'networked' practice, 'design intelligence', 'multidisciplinarity', 'holistic approach to problem-solving', rather than presenting supposedly post-ideological alternatives to cope with the present reality of production, appear more like ideological constructs to conceal such a reality, which is actually based on precarity and existential blackmail. In opposition to such an ideology, we are experiencing today a resurgence of a new engagement for architecture, promised by so-called 'activist architecture'. Yet activist architects seem more involved in representing other people's struggles, often in exotic third-world contexts, while overlooking their own condition as architectural producers. ${ }^{62}$

In 1934, Walter Benjamin already warned against two analogous approaches in a talk titled 'The Author as Producer'. At that time, these tendencies were epitomised by the literary movements of the Neue Sachlichkeit (New Objectivity) and of Aktivismus (Activism). New Objectivity celebrated the achievements of industry and technique, but by monumentalising and aestheticising its result, it ended up concealing the violence and exploitation that made it possible. On the other hand, Activism was a literary movement that unveiled the harsh living conditions in which the proletariat had to live, and advocated a future advent of socialism in which human values would finally triumph. Despite their good intentions, activist intellectuals ended up talking about the proletariat, while ultimately maintaining their bourgeois position and assuming the role of external sympathisers of the proletariat, its wealthy patrons. ${ }^{63}$

Contrary to these two approaches, Benjamin 
saw in Brecht and Weill's theatre a third possibility for the intellectual's renewed engagement. The problem for Benjamin is not about the content of the work, but the way in which it acknowledges and positions itself in relation to the production of its day. The work of art should not provide an aesthetic representation of technique. On the contrary, new techniques, according to Benjamin, already produce changes in collective perceptive habits: in other words, they produce a new aesthetics. The work of art should then recognise such aesthetic mutation and reverse-engineer it, in order to turn it into a weapon in the hands of the proletariat. Intellectuals should recognise their position as producers and become actively engaged in a conscious process of becoming proletarian. ${ }^{64}$

Meyer's attitude as an intellectual is strikingly similar. Through his practice he showed that the capitalistic development of the New World, if left alone, will not free our lives. Instead, we should recognise, isolate and accelerate the elements of liberation and autonomy that are immanent in our present reality. Perhaps we should realise that Hannes Meyer's prophecy should be taken even further; that architectural practice is not collaborative enough; that our buildings are not generic enough; that BIM should be more standardised; that schools are not sufficiently factories of knowledge; and that our labour time is not sufficiently merged with our lives. All the apparatuses that prevent the total collectivisation of architecture should be removed, relieving the anxiety imposed through precarity on the life of architect. Meyer showed the necessity of a political project to achieve what architecture alone cannot. Such a project has already been set in motion through the proposals of political movements across the globe: the elimination of debt, tuition fees and the introduction of a universal basic income are its concrete demands.

\section{Notes}

1. For the life of Hannes Meyer, see Meyer's own autobiographical notes in Claude Schnaidt, Hannes Meyer: Buildings, Projects and Writings (Teufen: Verlag Arthur Niggli AG, 1965); Klaus-Jürgen Winkler, Der Architekt hannes meyer: Anschauungen und Werk (Berlin: VEB Verlag für Bauwesen, 1989).

2. Andrew Saint, The Image of the Architect (New Haven and London: Yale University Press, 1983), 137.

3. Walter Gropius, 'Letter to Tomàs Maldonado from 24 November 1964', Ulm 9/10 (1964).

4. For an account of the history of the Bauhaus, see Hans M. Wingler, Bauhaus: Weimar, Dessau, Berlin, Chicago (Cambridge, MA: The MIT Press, 1978).

5. Gropius declared the programme for the new Dessau Bauhaus in a 1926 leaflet that he published under the title Bauhaus Dessau-Principles of Bauhaus Production, which was indebted to the original ideas of the Deutsches Werkbund of the merging of art into applied crafts. Kandinsky responded to this text with an article in the Bauhaus magazine in which he pleaded for the discarding of all 'purposes alien to art' and advocated teaching the internal laws of composition in painting. See Wingler, 109.

6. Francesco Dal Co, 'Hannes Meyer e la venerabile scuola di Dessau', in Hannes Meyer, Architettura o rivoluzione, ed. Francesco Dal Co (Padua: Marsilio, 1969).

7. Éva Forgács, The Bauhaus Idea and the Bauhaus Politics (Budapest: Central European University Press, 1995), 161.

8. Hannes Meyer, 'The New World, 1926', in Claude Schnaidt, Hannes Meyer, 91-94, originally published as 'Die neue Welt', Das Werk 13, no. 7 (1926).

9. Ute Poerschke, 'Hannes Meyer: Connecting Poetics and Ethics', Proceedings of the Conference Reconciling Poetics and Ethics in Architecture held at the Canadian Centre for Architecture CCA and McGill University (Montreal, 2007).

10. Meyer, 'The New World, 1926', 93

11. See, for example, Gropius's 1919 Bauhaus manifesto. Walter Gropius, Idee und Aufbau des Staatlichen Bauhaus (Weimar: Bauhausverlag, 1919). An English 
translation titled Manifesto and Program of the State Bauhaus can be found at bauhaus-online.de (accessed 26 January 2015).

12. But only after Mies van der Rohe refused the appointment. For this reason, Meyer later defined himself a 'stopgap'. See Hannes Meyer, 'My Dismissal from the Bauhaus, 1930: Open letter to the Oberbürgermeister Hesse, Dessau', in Claude Schnaidt, Hannes Meyer, $10-105$.

13. Dal Co, 'Hannes Meyer e la venerabile scuola di Dessau', 47-8.

14. Claude Schnaidt, Hannes Meyer, 39-41.

15. Hannes Meyer 'Ansprache an die Studentenvertreterhaus Anlass seiner Berufung auf den Direktorsposten', April 1928, Italian trans. 'Discorso ai rappresentanti studenteschi in occasione della sua nomina a direttore del Bauhaus', in Hannes Meyer, Architettura o rivoluzione, 85.

16. Ibid., 85.

17. 'Bauhaus - junge menschen kommt ans bauhaus!', publicity brochure for the Bauhaus (1929), cit. in ibid., 43.

18. Hannes Meyer, 'Bauhaus Dessau 1927-30', 111.

19. Such a criticism can be summarised by Mies's joke, reported by Walter Gropius: 'His philosophy culminates in the assertion that "life is oxygen plus sugar plus starch plus protein",' to which Mies promptly retorted: 'Try stirring all that together; it stinks.' Walter Gropius, 'Letter to Tomàs Maldonado', 70.

20. Hannes Meyer, 'bauen, 1928' and 'bauhaus and society, 1929', in Claude Schnaidt, Hannes Meyer, 95-101.

21. These parameters are the following: '1. sex life 2. sleeping habit 3. pets 4 . gardening 5. personal hygiene 6. protection against weather 7 . hygiene in the home 8. car maintenance 9 . cooking 10 . heating 11 . insulation 12. service.' Hannes Meyer, 'bauen, 1928', 97.

22. Hannes Meyer, 'bauhaus and society', 101.

23. Ibid., 99-101.

24. Hannes Meyer, 'My Dismissal from the Bauhaus', 103. 25. Ibid., 105.

26. Walter Gropius, 'Letter to Tomàs Maldonado', 70.
27. Hannes Meyer, 'Introduction to the Bauhaus Dessau 1928-1930 exhibition' (1931), Italian trans. 'Dal catalogo della mostra viaggiante del Bauhaus in Urss, 1931. Introduzione di Hannes Meyer', in Hannes Meyer, Architettura o rivoluzione, 104.

28. 'I am going to work in the Soviet Union, where a true proletarian culture is in the making, where socialism is born, and where the society for which we have fought in the capitalist regime, already exists.' Hannes Meyer, 'Interview with Hannes Meyer', Sovremennaya Architektura 5 (1930), cit. in Hannes Meyer, Architettura o rivoluzione, 56.

29. Hannes Meyer, Bauen, Bauarbeiter, und Techniker in der Sowietisch-union, conference held on 13 October 1931 in Berlin and published in Das Neue Russland 8, no. 9 (1931). Italian trans. 'L'edilizia, gli operai e i tecnici nell'Unione Sovietica', in Hannes Meyer, Architettura o rivoluzione, 110-114.

30. The first of his theses on Marxist Architecture declares, in fact, the end of architecture itself: 'architecture [arkitektur] is no longer architecture [baukunst]. building has become a science. architecture is the science of building [bauwissenschaft].' Hannes Meyer, 'These über Marxistische Architektur', in Hannes Meyer, Bauen und Gesellschaft. Schriften, Briefe, Projekte, eds. Lena Meyer-Bergnen and Klaus-Jürgen Winkler (Dresden: VEB Verlag der Kunst, 1980). Italian trans. 'L'architettura marxista', in Hannes Meyer: Architettura o rivoluzione, 159-161.

31. Hannes Meyer, 'Wie ich arbeite', originally published in Russian in Architektura SSSR 6 (1933). The original German manuscript from the author is published in Hannes Meyer, Bauen und Gesellschaft, 100. Italian trans. 'Il mio modo di lavorare', in Hannes Meyer, Architettura o rivoluzione, 123-7.

32. Hannes Meyer, 'L'architetto nella lotta di classe', in Hannes Meyer: Architettura o rivoluzione, 118. Originally published as 'Antworten auf Fragen der Prager Architektengruppe "Leva Fronta” (1933)', now in Hannes Meyer, Bauen und Gesellschaft, 121-128.

33. Hannes Meyer, 'L'architetto nella lotta di classe', 119.

34. Hannes Meyer, 'Bauhaus Dessau 1927-30', 113. 
35. This is particularly clear in Klaus Wingler's rendering of the second Bauhaus director in his Bauhaus: Weimar, Dessau, Berlin, Chicago.

36. 'The introduction to this book also presents a picture of Hannes Meyer as Claude Schnaidt sees him, a subjective picture.' Arthur Niggli, 'Publisher's epilogue', in Claude Schnaidt, Hannes Meyer, 121-22.

37. Hannes Meyer: Architettura o rivoluzione.

38. Ezio Bonfanti et al. (eds.), Architettura Razionale (Milan: Franco Angeli, 1977), 43.

39. See, for example, the catalogue of the exhibition at the Bauhaus Archive in Berlin, Werner Kleinerüschkamp (ed.), Hannes Meyer 1889-1954: Architekt, Urbanist, Lehrer (Berlin: Bauhaus-Archiv, 1989); Klaus-Jürgen Winkler, Der Architekt Hannes Meyer: Anschauungen und Werk; the issue Bauwelt 44, (1989); and Martin Kieren, Hannes Meyer, Dokumente zur Frühzeit, Architektur- und Gestaltungsversuche 1919-1927 (Teufen: Verlag Arthur Niggli AG, 1990).

40. Tomas Maldonado, 'Is the Bauhaus Relevant Today?' Ulm 8/9 (September 1963): 5-13, and the subsequent debate on UIm 9/10 (November 1964), with letters by Walter Gropius, Reyner Banham and Gillo Dorfles.

41. For an English introduction on negative thought and the Venice school, see Pier Vittorio Aureli, 'Intellectual Work and Capitalist Development: Origins and Context of Manfredo Tafuri's Critique of Architectural Ideology', Site 26-27, (2009).

42. For the definition of 'exalted rationalism', see Aldo Rossi, 'Introduzione', in Étienne-Louis Boullée, Architettura. Saggio sull'arte, trans. Aldo Rossi (Padua: Marsilio, 1967). As Winfried Nerdinger has noted, Meyer's architecture is much more subtle and complex than his own reductionist declarations. See Winfried Nerdinger, 'Hannes Meyer e il "rosso sconveniente"', Casabella 565 (1990): 30-35.

43. Anne Kockelkorn, Axel Sowa, 'Zurich, 1971: A Conversation on the Housing Question, Academic Intrigue, and an Italian Maestro. Conversation with Bruno Reichlin and Jörn Janssen' in Candide, no. 7 (Oct. 2013): 113-140.

44. Janssen's contribution in Hannes-MeyerGeburtstagskomitee (ed.), Hannes Meyer - Beiträge zum 100. Geburtstag. Internationales Symosium (Weimar: Hochschule für Architektur und Bauwesen Weimar, 1990).

45. Hilde Heynen, 'Architecture between Modernity and Dwelling: Reflections on Adorno's "Aesthetic Theory". Assemblage, no. 17 (April 1992): 79-91.

46. K. Michael Hays, Modernism and the Posthumanist Subject: The Architecture of Hannes Meyer and Ludwig Hilberseimer (Cambridge, MA: The MIT Press, 1995).

47. See, for example, the extensive blogging activity by Ross Wolfe on thecharnelhouse.org.

48. Joan Ockman, 'Theory and Practice', Assemblage, no. 41 (April 2000): 51.

49. For a critical overview of the academic success of the so-called Italian theory, see Matteo Pasquinelli, 'The so-called Italian Theory and the Revolt of Living Knowledge', Uninomade (13 April 2011), accessed June 2015, http://www.uninomade.org/ italian-theory-en/.

50. Bernardina Borra, 'Hannes Meyer: Co-op Architecture', San Rocco 6 (2013); Bernardina Borra, ‘Co-op Architecture: The Architect as Organizer, Architecture as Collective Class Consciousness', in id., 'The Architecture of Cooperation: A Project for Organizing Collective Creativity', unpublished PhD dissertation manuscript (Delft: TU Delft, 2014).

51. Pier Vittorio Aureli, 'The Theology Of Tabula Rasa: Walter Benjamin and Architecture in The Age of Precarity', Log 27 (Spring 2013).

52. Mario Carpo, The Alphabet and the Algorithm (Cambridge, MA: MIT Press, 2011).

53. On the consequences of the introduction of BIM in architecture, see Peggy Deamer, 'BIM and Contemporary Labor', Pidgin, no. 12 (2012).

54. Carpo, The Alphabet and the Algorithm, 125.

55. See, for example, community-maintained projects such as bimserver.org, openbim.org and osbim.org.

56. See also Claire Jamieson, (ed.), The Future for Architects? (London: The Royal Institute of British Architects: 2001), accessed November 2013, http:// buildingfutures.org.uk.

57. For a critique of the university within contemporary 
capitalistic development, see The Edufactory

Collective, Towards a Global Autonomous University

(New York: Autonomedia, 2009).

58. For an account of the political, economic and existential role of debt in post-Fordism, see Maurizio Lazzarato, The Making of the Indebted Man: Essay on the Neoliberal Condition (New York: Semiotext(e), 2012).

59. An account of architectural practice after the 2008 crash is contained in Powerhouse Company (ed.), Rien ne va plus: Texts on the economic crisis and its intricate relation to architecture (Maastricht: NAiM / Bureau Europa, 2009).

60. On the affective and existential effects of cognitive labour, see Franco Berardi, The Soul at Work: From Alienation to Autonomy (New York: Semiotext(e), 2009).

61. This kind of approach was inaugurated by the seminal Robert E. Somol and Sarah Whiting, 'Notes Around the Doppler Effect and Other Moods of Modernism', in Perspecta 33: Mining Autonomy, ed. Michael Osman, Adam Ruedig, Matthew Seidel, Lisa Tilney, (Cambridge MA: The MIT Press, 2002), but it reached extreme consequences in the writings of Michael Speaks. See Michael Speaks, 'Design Intelligence and the New Economy', Architectural Record 190, no.1 (January 2002): 72-79; and Michael Speaks, 'After Theory', Architectural Record 193, no. 2 (June 2005): 72-75.

62. For an idea of the new socially-oriented approaches in architecture, see Nishat Awan, Tatjana Schneider, and Jeremy Till, Spatial Agency: Other Ways of Doing Architecture (London: Routledge, 2011) and Did Someone Say Participate?: An Atlas of Spatial Practices, eds. Markus Miessen and Shumon Basar, (Cambridge, MA: The MIT Press, 2006).

63. Walter Benjamin, 'The Author as Producer,' New Left Review I, no. 62 (July-August 1970).

64. Ibid.

\section{Biography}

Amir Djalali writes about the politics of the production of architectural knowledge. His $\mathrm{PhD}$, developed within the programme 'The City as a Project' at the Berlage Insitute/TU Delft, explored the drive towards commonality and collectivity in five episodes taken from the history of Western modern architecture. Amir taught studios and theory seminars at the Berlage Institute, TU Delft and the Rotterdam Academy of Architecture. In 2013 he co-founded Behemoth Press, a multi-modal think-tank platform devoted to the exploration of the architectural project and the power relations that it entails. Since 2012 he collaborates with the Rotterdam-based architecture office Matteo Mannini Architects. 
